\title{
Strength of Materials Teaching from Active Learning
}

\author{
Ensino de Ciência dos Materiais a partir da Aprendizagem Ativa
}

\author{
Luciano Andreatta Carvalho da Costa (luciano-costa@uergs.edu.br) \\ Universidade Estadual do Rio Grande do Sul - UERGS
}

\begin{abstract}
The Young's modulus can be understood as a generalization of the constant of proportionality k, studied in High School Physics, when working with elastic force. This is an extremely relevant concept for all disciplines in the field of materials and structural calculation in Engineering. This paper presents the results of a research that evaluated the students' understanding of Young's modulus based on active learning and carrying out a practical experiment using rubber ties. The theoretical framework emphasizes the need for student action in the construction of knowledge. The methodology had two approaches: a quantitative one, based on a hypothesis test for proportions, which compared the average scores obtained by students from two groups in a test carried out at the end of each pedagogical intervention (the control group, which received lectures, and the second group, which received lectures combined with practical experiments); and a qualitative one, which occurred during the conduct of the experiment carried out by the second group. There was a quantitative improvement in the results obtained from students who carried out the practical experiment for questions of a conceptual nature and a statistical difference between the performance of conceptual and calculation questions in both groups. From a qualitative point of view, there was a strengthening of student-centered learning, in the group that carried out the practical experiment. It is concluded that the experiment demonstrated the potential of practical activities for the construction of theoretical concepts, especially in the perspective of student-centered learning, with a focus on the interpretation of phenomena and conceptual articulation, relating and adapting the theory to the experiment.
\end{abstract}

Keywords: Active Learning; Engineering Education; Strength of Materials; Hands-on experiments.

Resumo: O módulo de Young pode ser entendido como uma generalização da constante de proporcionalidade $\mathrm{k}$ estudada na Física do Ensino Médio, quando se trabalha a força elástica. Trata-se de um conceito extremamente relevante para todas as disciplinas da área de materiais e de cálculo de estruturas nas Engenharias. Este artigo apresenta os resultados de uma pesquisa que avaliou a compreensão do Módulo de Young por parte dos estudantes com base na aprendizagem ativa e na realização de um experimento prático utilizando-se atilhos de borracha. O referencial teórico enfatiza a necessidade de ação do aluno na construção do conhecimento. A metodologia teve duas abordagens: uma quantitativa, a partir de um teste de hipóteses para proporções, que comparou as pontuações médias obtidas pelos estudantes de dois grupos em um teste realizado no final de cada intervenção

Recebido em: 26/05/2020

Aceito em: $23 / 12 / 2020$ 
pedagógica (o grupo controle, que teve aulas expositivas, e o segundo grupo, que teve aulas expositivas combinadas com o experimento prático); e outra qualitativa, que ocorreu ao longo da condução do experimento realizado pelo segundo grupo. Houve uma melhora quantitativa nos resultados obtidos pelos estudantes que realizaram o experimento prático para questões de natureza conceitual e uma diferença estatística entre o desempenho das questões conceituais e de cálculo nos dois grupos. No ponto de vista qualitativo, observouse o fortalecimento da aprendizagem centrada no estudante, no caso do grupo que realizou o experimento prático. Conclui-se que o experimento evidenciou o potencial das atividades práticas para a construção de conceitos teóricos, em especial na perspectiva da aprendizagem centrada no estudante, com foco na interpretação dos fenômenos e na articulação conceitual, relacionando e adaptando a teoria ao experimento.

Palavras-chave traduzidas: Aprendizagem ativa; Educação em Engenharia; Resistência dos Materiais; Experimentos práticos.

\section{INTRODUCTION}

Considering the context of technological training aligned with such needs for the 21 st century, some of the processes applied in engineering education need to be readjusted, and in some cases, undergo a significant transformation. According to Rifkin (2014), we are going through a moment of profound technological transformation with a significant impact on the production of consumer goods and the provisioning of services, including training, particularly in the technological area. The effective automation of processes and artificial intelligence, combined with increasingly powerful data processing, is drastically reducing jobs worldwide. Moreover, using a 3D printer as an example, Rifkin defines the concept of a prosumer - a combination of a producer and a consumer-based on what he calls a sharing and self-production economy. Thus, improving the pedagogical processes in engineering courses has become even more important.

The interactionist perspective of learning, based on an epistemology starting from an action to describe knowledge construction processes, is even more aligned with the context outlined above. Numerous studies on engineering and science education have explored this perspective (ROJTER, 2009; BRIEDE, 2013; VIIRI, 1996; VENQUIATURO et al; MORO et al), showing the extent to which education in the technological area can be improved by its application.

The search for alternatives using an interactionist perspective is relevant in the field of structural engineering education. Surovek and Rassati (2017) and McCrum (2016) have 
addressed the extent to which traditional teaching in this area may be inhibiting the creativity of students, which is of fundamental importance for professional engineering practices.

In this context, this study focused on exploring Young's modulus, a concept that serves as the basis for all disciplines in the Engineering courses in the area of Materials and Structures. In addition, Young's modulus can also be understood as a generalization of the proportionality constant of the spring, studied in High School Physics.

Figure 1 presents the stress $\mathrm{x}$ strain graph, as well as the Young's modulus, which represents the relationship between stress and strain, obtained from Hooke's Law.

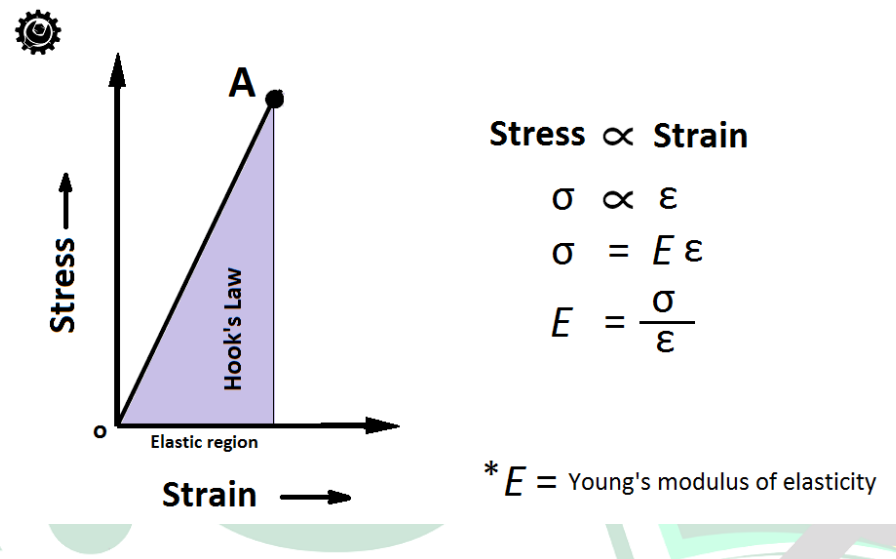

Figure 1 - Modulus of Elasticity

Source: What is Young's Modulus or Modulus of Elasticity? (2020)

It is a generalization of the Elastic Force obtained in the stretching or shortening of the spring, as can be seen in Figure 2.

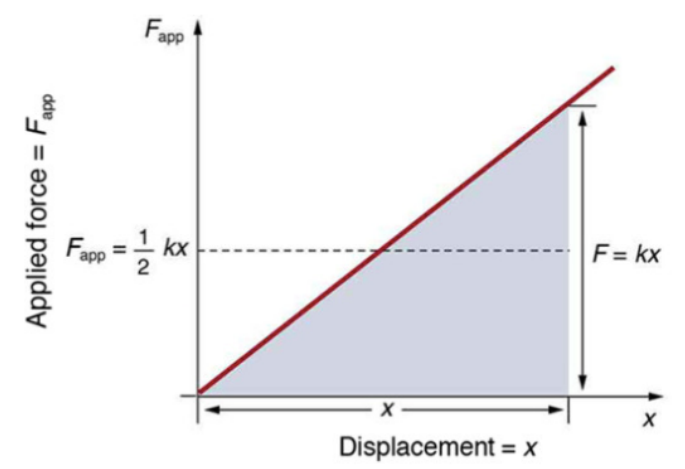

Figure 2 - Spring's Elastic Force

Source: Hooke's Law: Stress and Strain Revisited (2020) 
The general objective of this article was to evaluate the extent to which active learning contributes to a better understanding of the concept of the Young's modulus.

\section{THEORETICAL REFERENCE}

\subsection{Kuhn's epistemological perspective}

Kuhn (1996) makes an important epistemological contribution when describing paradigmatic transformations in different scientific revolutions. For the author, the scientific discoveries that have occurred throughout history, from Copernicus to Einstein, have consistently promoted a transformation 'in the inner world from which scientific work was carried out'.

Kuhn (1996) adds that some aspects of teaching in science, technology, engineering, and mathematics (STEM) must be considered for such paradigmatic transformations to occur, advancing the fields of science and technology. The author emphasises the importance of active student participation in applying concepts for solving problems, giving as an example the study of Newtonian physics. From Kuhn's perspective, physics laboratories must not only verify a hypothesis, but adapt the theory to the experiment (ARRUDA et al, 2001). In this context, there must be a conceptual articulation, where efforts must be directed towards the interpretation of situations and the resolution of problems (OSTERMANN, 1996).

\subsection{Active Learning}

According to Gadotti (1998), Dewey was the first to formulate this pedagogical ideal, stating that teaching should take place through action ('learning by doing') and not through instruction, as education continually reconstructs the concrete, active, and productive experience of each individual. For Dewey, a five-stage scale of thinking takes place in the presence of a problem:

(i) A felt difficulty

(ii) Analysing the difficulty

(iii) Finding alternatives to solve the problem 
(iv) Experimenting with various solutions until a solution is approved based on a mental test.

(v) Applying the final proof of the proposed solution, which must be assessed scientifically.

The student-centered learning promoted by progressive education was also described by Kilpatrick, who used active and creative student-centered methods. Kilpatrick, Stevenson, and Collings revolutionised North American pedagogy through the project method, applying four classifications: production, consumption, problem-solving, and an improvement of certain techniques (GADOTTI, 1998).

A professor's most common mode of intervention comprises an explanation regarding how each calculation is performed or how a problem is solved, and evaluating whether the procedures applied by a student are 'right' or 'wrong' based on previously established models. This traditional teaching practice allows the student to reproduce the professor's reasoning, instead of instigating their own personal reasoning (GOULART, 1993). Cabral (2015) called this traditional mode of teaching current traditional teaching (CTT), where teachers teach in exactly the same way they learned (SUÁREZ SILVA; FORTES BRAIBANTE; 2018).

\subsection{Piaget's theory in physical experiments}

Piaget also based his theory on active learning by establishing the epistemological foundations of constructivism (PIAGET, 1981). Despite having focused his studies on four stages of learning that start during childhood, his innovative proposal, that learning is based on the relationship between subject and object (reality), has transformed the different levels of education, from childhood to adulthood.

Goulart (1996) also mentioned Piaget's theory for teaching in STEM, more specifically, in the teaching of the flexibility of metal rods and their properties. By bending metal rods of different dimensions, but with the same elastic properties, Piaget classified the probable responses given by an individual according to their own stage of learning. These stages range from the pre-operational stage, where an individual has not yet structured any concept related to the mechanical behaviour of the rods, to the formal 
operational stage, where the subject systematises the concepts worked on through an experiment.

Similar to Piaget's theory, which was proposed in a study on the flexibility of metal roads, this paper presents different strategies for active learning developed and experienced over 2 years of research into the teaching of the strengths of different materials. These methods primarily aim to develop the ability of students to understand the Young's modulus and the physical properties involved in this concept.

\section{MATERIALS AND METHODOS}

To achieve the proposed objectives, two methodological approaches were adopted: the first, with a quantitative bias, where the performances of two groups were compared: the first in 2014, without applying the practical experiment as a control, and the second in 2015, using a practical experiment. The same final test was applied to both groups after the pedagogical intervention.

The second one, with qualitative bias, sought to evaluate how much the experiment favored active and student-centered learning (PIAGET, 1981; GADOTTI, 1998) and the approximation between theory and experimentation (ARRUDA et al, 2001; OSTERMANN, 1996).

\subsection{Quantitative Approach}

The quantitative methodology used was based on an approach by Campbell and Stanley (2015), who described an experiment conducted with two groups, with only one of them being subjected to treatment $X$ (in our case, the practical experiment). The group not subjected to treatment was the control group (in our case, the 2014 group). To compare the two groups, hypothesis tests considering two different proportions were conducted in two ways: using unilateral alternative hypotheses (on the right) to determine whether the proportion of correct answers by the students in 2015 was significantly higher than that of the students in 2014; and using bilateral alternative hypotheses, to determine whether there were significant differences between the proportion of correct answers to the conceptual and calculation questions. 
These comparisons were made individually for 6 conceptual questions, 4 calculation questions, and for all 10 questions as a group. The total sample size used in 2014 was 140, with 14 students answering 10 questions, and in 2015, it was 240, with 24 students also answering 10 questions.

This dataset was adequate in showing that most comparisons are significant, as detailed below. The margin of error was $5 \%$.

Considering the calculation under a normal distribution, where the literature suggests an $\mathrm{n}$ of greater than 50 , satisfactory values were obtained for the confidence intervals, considering a 95\% significance. The confidence intervals along with their percentages are presented in a later section describing the statistical results.

It should be noted that the $\mathrm{n}$ of the sample, completely independent, would correspond to 14 . However, to achieve significant feasibility in the results, the $\mathrm{n}$ required for binomial proportions is very high and, in many cases, difficult to achieve in experiments similar to this one. In addition, each student should answer only one question to ensure complete independence. However, as the questions answered by the students are not the same, there is a point of independence between them, because when the student starts to solve a new question, a new reasoning and a new reflection begins, guaranteeing a certain degree of independence between different questions answered by the same student.

For instance, the calculation of sample size to detect $10 \%$ difference between the proportions of correct answers in a single question for a test power of $80 \%$ and uncertainty of 5\% (typical values), considering the approximation of the central limit theorem, is 376 students in each group.

However, in this work, for considerably smaller sample sizes, it was already possible to detect a significant difference in the proportions of correct answers. For example, the statistical analysis presented in the article that has the smallest sample sizes is precisely that of Question 6, in the comparison between the classes of 2014 and 2015. In this case, in 2014, 6 out of 14 students answered the question correctly and in 2015, 19 of the 24 got it right. The p-value resulted in 0.011 . 
This study was developed based on an understanding that the stress versus strain diagrams of different materials are fundamental in the science regarding the strength of materials applied to different engineering practices. Therefore, we developed the materials described below.

A test was developed with questions referring to the strength of materials subject to concepts regarding the elastic phase, different stress versus strain diagrams, ductility, brittleness, specific stress and strain, and shear, contact, and normal stress. This questionnaire aimed at quantifying the learning of the two groups. One group was exclusively exposed to traditional classes (2014). The other group, in addition to the traditional method, conducted an activity using a practical experiment (2015) based on learning through a method proposed by Dewey, and to a certain extent, the experiments with metal rods proposed by Piaget (GOULART, 1996).

The following text presents the 10 questions performed in the test, the first 6 being conceptual and the last 4 being calculated:

\section{CONCEPTUAL QUESTIONS}

1) As for the elastic phase of the stress-strain diagram, it is INCORRECT to state that:

a) In this phase the material is able to return to its original deformation state after the load is removed

b) The relationship between stress and strain is linear

c) After deforming and reducing the load to zero, there is a residual deformation

d) The modulus of elasticity is the slope of the graph at this stage

e) It is the first phase of the stress-strain diagram

The following figures refer to questions 2 and 3.

б Stress vs. Strain Diagram of certain types of steel

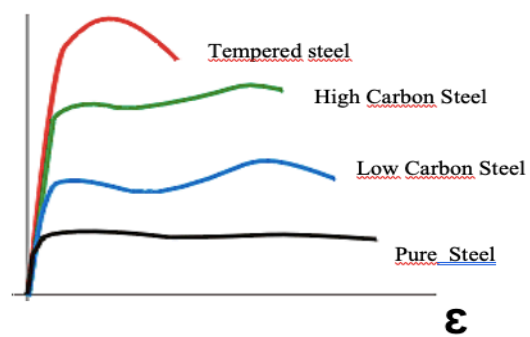

Typical behaviour of stress-strain curves

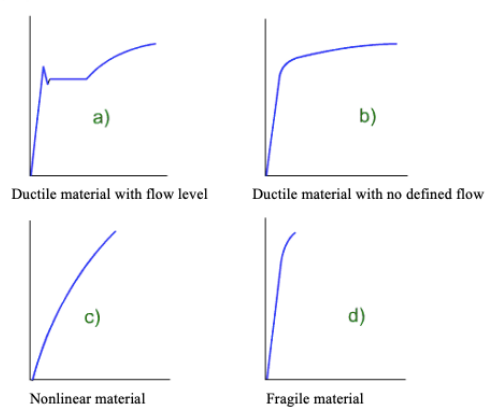

Figure 3 - Questions 2 and 3

Source: Beer \& Jonhston (2006) 
2) Consider the following statements:

I) Pure steel has a smaller plasticisation zone than hardened steel

II) The higher the carbon content is, the greater the flow limit

III) The flow limit of common steel is the largest of all Based on Figure 2, the correct items are as follows:

b) II only

c) III only

d) I and II only

e) I and III only

Justify your answer:
3)Consider the following statements:

I) A ductile material has a linear initial phase

II) A fragile material has a

large area of plasticisation.

III) Stress is reduced less in the

plasticisation zone than in the

elastic phase

Based on Figure 3, the correct items are as follows:

a) I only

b) II only

c) III only

d) I and II only

e) I and III only

Justify your answer:

Based on the figure below, answer questions 4, 5 and 6
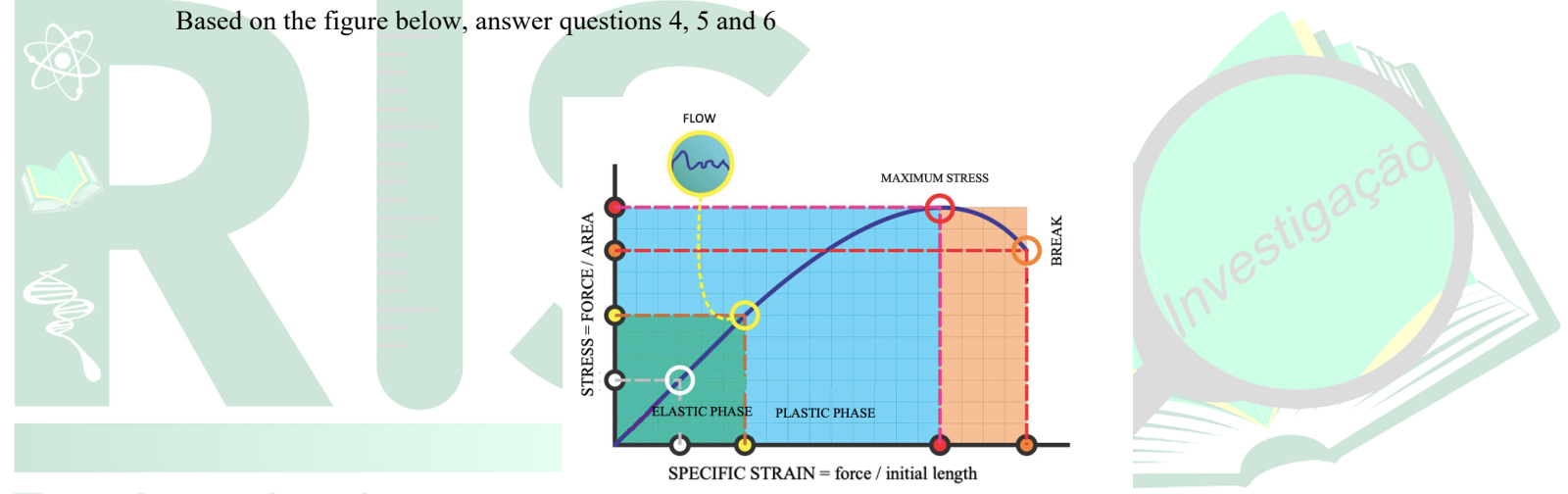

Figure 4-Questions 4, 5 and 6

Source: Sistemas Estruturais Na Arquitetura (2014)

4) Show on the graph where the yield point is and explain what happens on the graph when the voltage exceeds the yield point.

5) Describe the plastic phase of the diagram.

6) How can we identify the modulus of elasticity in the figure?

\section{CALCULATED QUESTIONS}

7) A steel bar with a length of $1.8 \mathrm{~m}$ increases its length by $2 \mathrm{~mm}$ when a tensile force of $15 \mathrm{kN}$ is applied. Knowing that $\mathrm{E}=200 \mathrm{GPa}$, determine: (a) the diameter of the bar, (b) the corresponding normal stress caused by the force. 
8) When the $\mathrm{P}$ force reached $10 \mathrm{kN}$, the wooden specimen shown in the figure failed under shear along the surface indicated by the dashed line. Determine the average shear stress across that surface at the time of failure. ANSWER: $7.407 \mathrm{MPa}$ column of wood supported by a concrete base on stable ground. Determine (a) the maximum contact stress on the concrete base, (b) the size of the base for which the average contact stress on the ground is 125 $\mathrm{kPa}$.

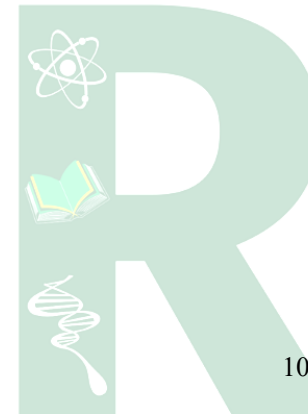

10) Two full cylindrical bars, $\mathrm{AB}$ and $\mathrm{BC}$, are welded together in $\mathrm{B}$ and subjected to a load as shown in the figure. Knowing that $\mathrm{d} 1=50 \mathrm{~mm}$ and $\mathrm{d} 2=30 \mathrm{~mm}$. Calculate the normal stress at the midpoint of (a) $\mathrm{AB}$ bar, (b) BC bar.

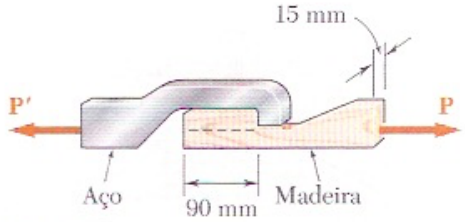

Fig. P1.15

Figure 5 - Question 8

Source: Beer \& Jonhston (2006)

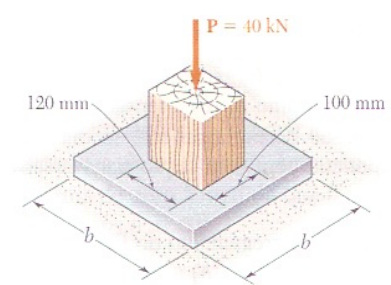

Fig. P1.20

Figure 6- Question 9

Source: Beer \& Jonhston (2006)

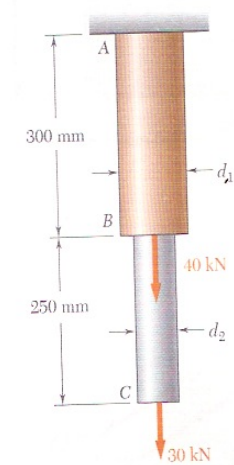

Fig. P1.1 e P1.2

Figure 7- Question 10

Source: Beer \& Jonhston (2006) 


\subsection{Qualitative Approach}

In the work with the second group, strategies were adopted to assess the qualitative aspects presented in the methodology. A didactic task based heavily on a hands-on experiment was carried out with students having the opportunity to conduct experiments and model the results. Under the guidance of a professor, four specimens of different dimensions were used by the students to conduct traction tests and elucidate the proportionality of the Young's modulus. Figure 8 shows how this experiment was conducted.

The material used to carry out the activities included the following:

- Four specimens:

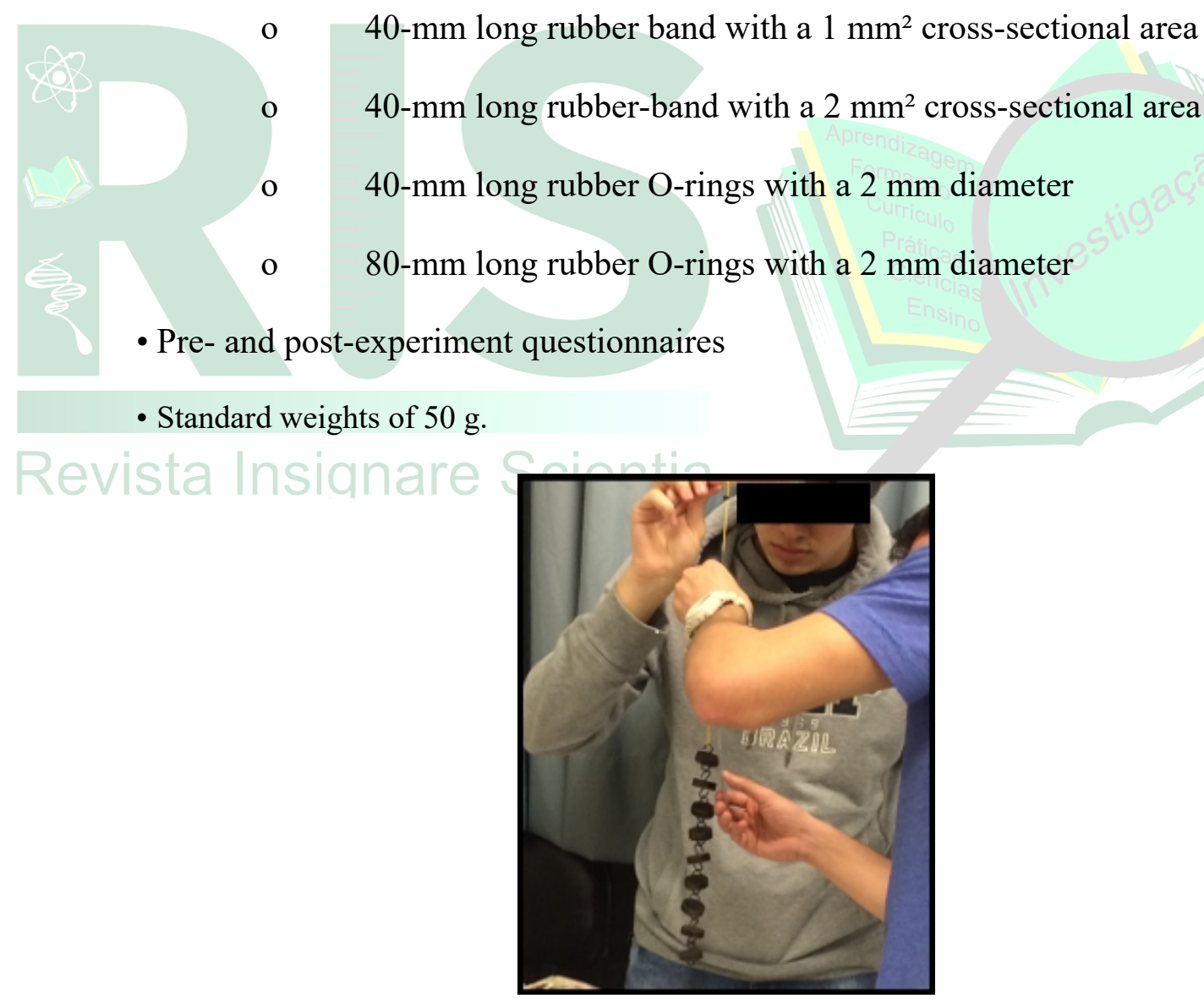

Source: The authors.

Figure 8 - Students conducting activities (2015) 
At the beginning of the experiment, prior knowledge related to the concept to be addressed was assessed based on the following pre-experiment question:

The force required to obtain a given elongation in two rubber-bands with different cross-sectional areas with the same initial length and the same material:

(a) Is not dependent on the section area

(b) Increases when the section area increases

(c) Decreases when the section area increases

After answering the question, the students conducted practical activities.

Figure 8 shows the development of a practice in which a $450 \mathrm{~g}$ mass is applied as a weight force on the specimen (rubber band with an initial length of $40 \mathrm{~mm}$ and an area of $1 \mathrm{~mm})$. The students measure the new length of the specimen after applying a force to it.

Figure 9 also shows the development of the practice in which a $500 \mathrm{~g}$ mass is applied as a weight force on the specimen (O-rings of $80 \mathrm{~mm}$ in initial length and $2 \mathrm{~mm}$ in diameter).

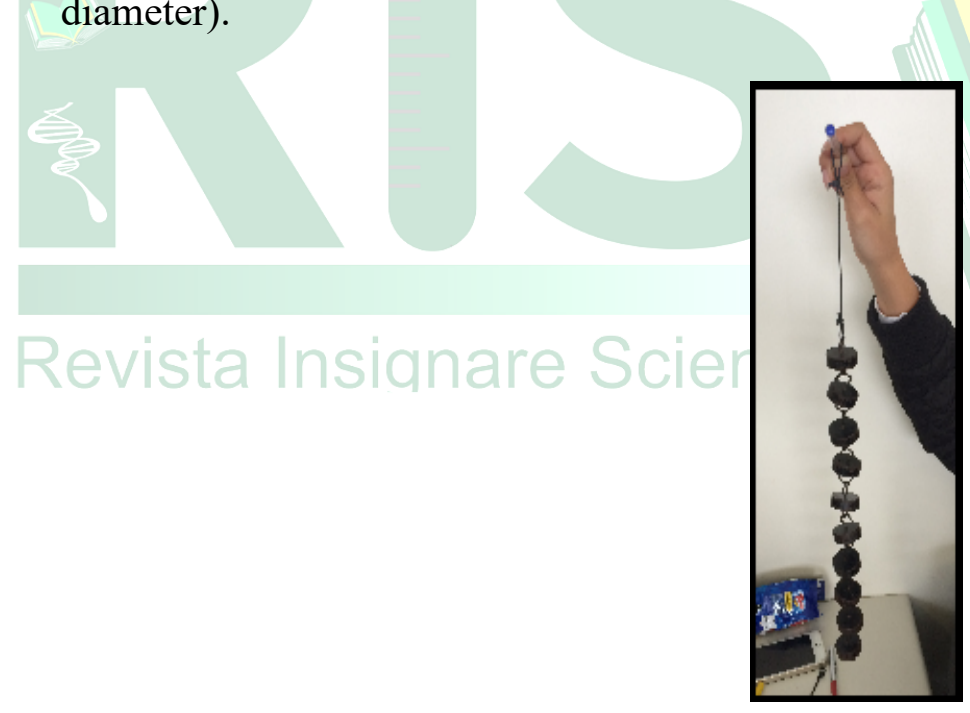

Source: The authors.

Figure 9 - Practical activity: ABP method

During the experiment, the students answered the following question based on the data measured during their practical experiments: 

a) remains the same
b) increases by up to $50 \%$ compared to rubber with area $\mathrm{X}$
c) increases more than $50 \%$ compared to rubber with area $\mathrm{X}$
d) decreases up to $50 \%$ compared to rubber with area $\mathrm{X}$
e) decreases more than $50 \%$ compared to rubber with area $\mathrm{X}$

After practical experience, the students answered one more question, also related to the practice concepts. This question is called the 'post-experiment' question, and an example is provided below:

Consider a steel bar with a length of $1.8 \mathrm{~m}$ and a diameter of $10 \mathrm{~mm}$ that has its length increased by $14 \mathrm{~mm}$ when a pulling force of $23 \mathrm{kN}$ is applied. Considering that we will apply a new force to another steel bar with the same length and a diameter of $13 \mathrm{~mm}$, the value of this force to obtain the same elongation must for values $\mathrm{kN}$

The alternative that correctly fills in the blanks is as follows:

a) increase; greater than 35

b) increase; between 25 and 35

c) decrease; between 18 and 22

d) decrease; of less than 18

In this scenario, a pre-experiment question, practical activity, and post-experiment question are repeated for the four types of specimen (used in both classes). The students are then requested to go to the computer lab, where they develop their stress versus strain diagrams.

Figure 10 shows a stress versus strain graph of an experiment conducted on a 40 $\mathrm{mm}$ long rubber-band with an area of $2 \mathrm{~mm}$. The modulus of elasticity of the material is $1.1243 \mathrm{MPa}$, and its square error is approximately 0.99 . 


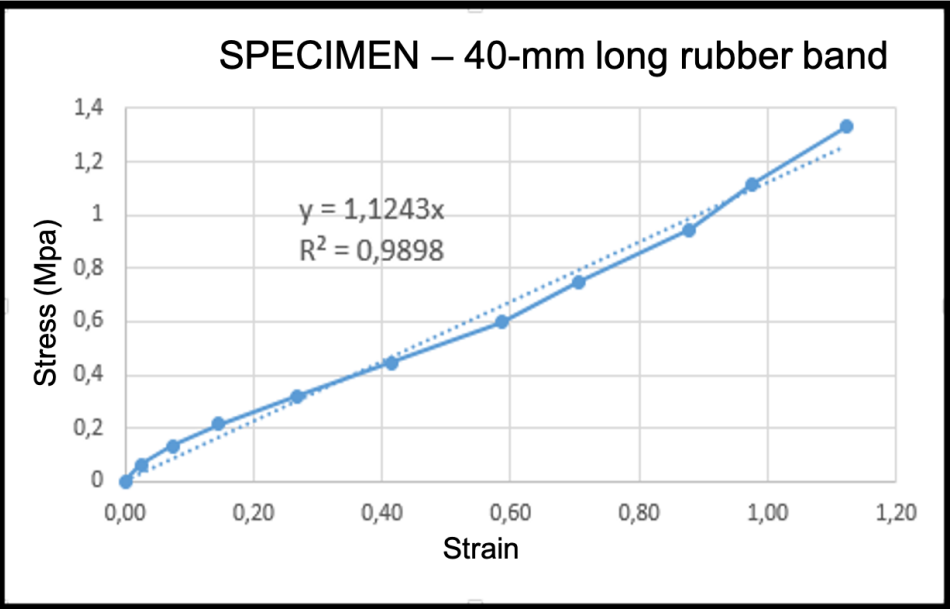

Source: The authors

Figure 10 - Stress $\times$ Strain diagram (specimen: 40-mm long rubber band with $1 \mathrm{~mm}^{2}$ area)

The construction of the graph shown in Figure 10 required the correction of the cross-sectional area of the samples, since, being a material with high deformability, the correction was essential to determine the stresses in each loading step. This exercise was relevant to take into account the qualitative aspects of the experiment, as will be described below.

\section{RESULTS}

\section{a. Quantitative aspects}

As mentioned in the methodological procedures, Tables 1, 2, and 3 summarise the values used. Symbols $C I_{95 \%}$ represent the confidence interval of the proportion at a $95 \%$ level. In addition, $\hat{p}$, in turn, is used for the sample proportion, as the number of correct answers $\mathrm{x}$ divided by the total number of questions $\mathrm{n}$ in the respective sample space.

Table 1 - Quantities and percentages of total correct answers

\begin{tabular}{|c|c|c|}
\hline & $\begin{array}{c}\mathbf{2 0 1 4} \\
\text { 14 students answering 10 } \\
\text { questions each }\end{array}$ & $\begin{array}{c}\text { 2015 } \\
\text { 24 students answering 10 } \\
\text { questions each }\end{array}$ \\
\hline$x$ & 102 & 197 \\
\hline$n$ & $140(14 \times 10)$ & $240(24 \times 10)$ \\
\hline$\hat{p}=\frac{x}{n}$ & $72.86 \%$ & $82.08 \%$ \\
\hline$C I_{95 \%}$ & $65.49 \%$ to $80.22 \%$ & $77.23 \%$ to $86.94 \%$ \\
\hline
\end{tabular}


Table 2 - Quantities and percentages of correct answers for conceptual questions

\begin{tabular}{|c|c|c|}
\hline & $\begin{array}{c}\mathbf{2 0 1 4} \\
\text { 14 students answering six } \\
\text { questions each }\end{array}$ & $\begin{array}{c}\mathbf{2 0 1 5} \\
\text { 24 students answering six } \\
\text { questions each }\end{array}$ \\
\hline$x$ & 50 & 104 \\
\hline$n$ & $84(14 \times 6)$ & $144(24 \times 6)$ \\
\hline$\hat{p}=\frac{x}{n}$ & $59.52 \%$ & $72.22 \%$ \\
\hline$C I_{95 \%}$ & $49.03 \%$ to $70.02 \%$ & $64.91 \%$ to $79.54 \%$ \\
\hline
\end{tabular}

Table 3 - Quantities and percentages of correct answers for calculation questions

\begin{tabular}{|c|c|c|}
\hline & $\begin{array}{c}\mathbf{2 0 1 4} \\
\mathbf{1 4} \text { students answering four } \\
\text { questions each }\end{array}$ & $\begin{array}{c}\mathbf{2 0 1 5} \\
\text { 24 students answering four } \\
\text { questions each }\end{array}$ \\
\hline$x$ & 52 & 93 \\
\hline$n$ & $56(14 \times 4)$ & $96(24 \times 4)$ \\
\hline$\hat{p}=\frac{x}{n}$ & $92.86 \%$ & $96.86 \%$ \\
\hline$C I_{95 \%}$ & $86.11 \%$ to $99.60 \%$ & $93.39 \%$ to $100 \%$ \\
\hline
\end{tabular}

The following conclusions can be drawn from the hypothesis tests using the data presented in Tables 1, 2, and 3 with a 5\% margin of error:

a) The proportion of total correct answers in $2014(72.86 \%)$ was significantly lower than that in $2015(82.08 \%)$, with $p=0.0171$.

b) The proportion of correct answers for the conceptual questions (from 1 to 6) in 2014 (59.52\%) is significantly lower than that in 2015 (72.22\%), with $p=0.0241$.

c) The proportion of correct answers in the calculation questions (from 7 to 10) in 2014 $(92.86 \%)$ was significantly lower than that in $2015(96.86 \%)$, with $p=0.1271$. 
d) The proportion of total correct answers for the conceptual questions (from 1 to 6 ) in 2014 and 2015 (69.35\%) is significantly different from the calculation questions (from 7 to 10$)$ in 2014 and 2015 (95.97\%), with $p=2.22 \cdot 10^{-16}$.

e) The proportion of correct answers for conceptual questions (from 1 to 6) in 2014 $(59.52 \%)$ is significantly different from the calculation questions (from 7 to 10 ) in 2014 $(92.86 \%)$, with $p=1.393 \cdot 10^{-5}$.

f) The proportion of correct answers for the conceptual questions (from 1 to 6) in 2015 $(72.22 \%)$ was significantly different from the calculation questions (from 7 to 10 ) in 2015 $(96.86 \%)$, with $p=1.07 \cdot 10^{-6}$.

In the above conclusions, $p$ is the value traditionally used in tests on the statistical significance.

\section{b. Qualitative aspects}

The activities carried out with the second group showed the importance of the students carrying out the practical experiment themselves. Unlike what is traditionally done, when students only watch the tests being performed, it was possible for students to "feel" and calculate the Young's Modulus of each sample, from the later usage of an electronic spreadsheet.

Active learning actually occurred, in the perspective presented by Piaget (1981), centered on the student, and with an approximation between theory and practice, based on the adaptation made with the use of rubber ties. 


\section{DISCUSSION}

Some inferences can be drawn from the quantitative and qualitative results described in the previous section, in light of the AL theory presented in the initial sections, particularly for engineering education. Initially, it is worth noting that the classroom represents a specific space, which to a certain extent, limits the statistical results obtained for this reality. However, we must continue conducting analyses and making reflections based on statistical studies using methods established in the literature. We previously mentioned in the methodology section the type of statistical and quantitative study that can be developed on research in teaching, which does not prevent us from also using qualitative approaches when performing the experiments.

According to the results, a significant improvement was first shown in the total number of correct answers in the 2015 group over the control (2014) (item a in the previous section). This result is relevant because the experiment was conducted by the same professor under conditions that were somewhat controlled.

The results obtained on items $b$ and $c$ align with the theoretical perspective presented on AL (an improvement was observed in the conceptual questions but not in the calculation questions). This may be because the calculation questions require a more mechanical approach to their resolution, which is easier to achieve because they can be solved with formulae obtained from textbooks. However, the author observed from almost 20 years of experience as a professor in the field of structures that the knowledge necessary for solving the calculation questions is more ephemeral, and is soon forgotten by the student, unlike conceptual questions, in which active learning plays a more significant role. The hands-on experiment was applied using rubber bands and with an adjustment of the stress versus strain curve on an electronic spreadsheet, allowing the concepts constructed by the students to become more consolidated and perennial. In addition, this adjustment of the curve also showed the Kuhnian paradigm present in the theoretical framework, from which an adaptation of the theory to the experiment occurs. Because a rubber tie is a material with a Young's Modulus well below those of the traditional materials used in Engineering, it was necessary to adapt the theory traditionally presented in textbooks. 
Items $\mathrm{d}$, e, and $\mathrm{f}$ reinforce to a certain extent the arguments above by showing a statistical difference between the performance of the students regarding the conceptual questions and the calculation questions for both groups. This result also meets the emphasis that, according to the Kuhnian perspective, must be given to the interpretation of physical phenomena (OSTERMANN, 1996).

Given the primary objective to construct the concept of the Young's modulus, special consideration should be given to the last conceptual question, which asks the student to identify such modulus on the graph shown in Figure 11.
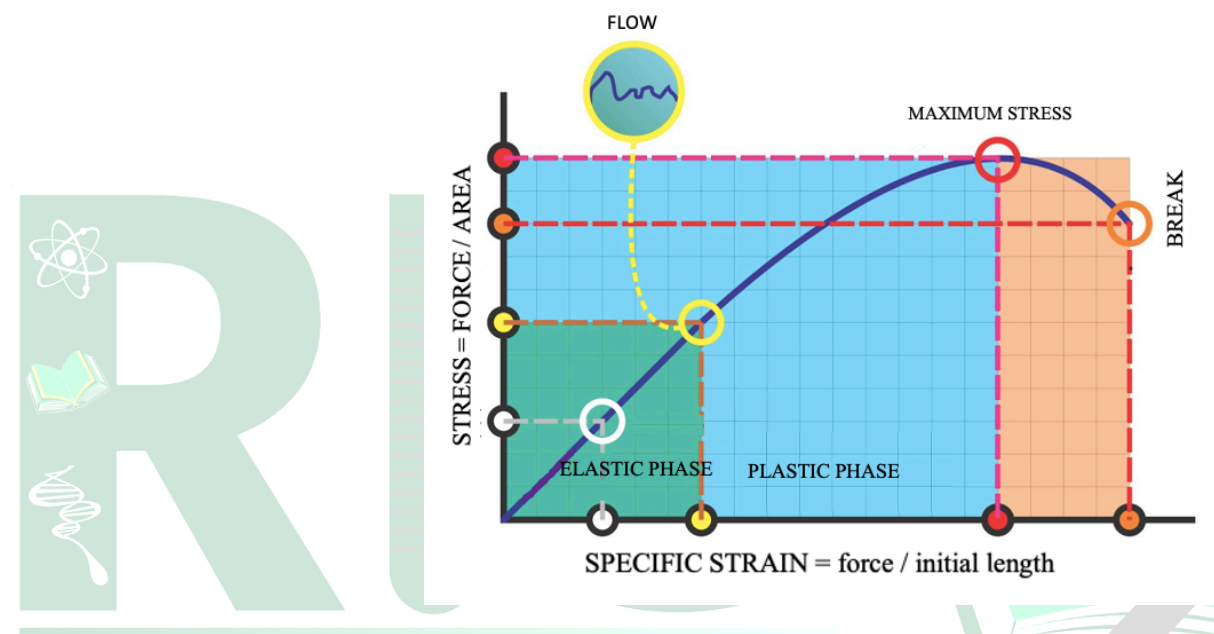

Figure 11 - Conceptual question on Young's modulus

Source: Sistemas Estruturais Na Arquitetura (2014)

Whereas the 2014 group answered 43\% of the questions correctly, the 2015 group correctly answered $79 \%$ of the questions. The effectiveness of the proposed approach can be inferred from the results of the hypothesis test when considering that the proportion of correct answers in the 2014 group is significantly lower than that of the 2015 group, at $\mathrm{p}=0.0114228$. This result is in line with the analyzes carried out by Piaget (1981), presented in the theoretical framework, which highlighted the importance of active learning for the understanding of the physical behavior of different materials. The qualitative approach carried out with the second group, especially regarding the different strategies used by students to determine the Young's Modulus of different materials, 
probably contributed to the good performance of the students in the second group in this last conceptual question.

Although this is a single result, a significant improvement in the percentage of correct answers was demonstrated. The results obtained for this question will make an important contribution to the final statistics.

\section{CONCLUSIONS}

When conducting the tasks, particularly the practical experiment, most of the students were committed to AL, and were highly engaged. Their difficulty in adapting to a didactic approach based on active learning is due to the fact that they are accustomed to CTT, which only requires the reproduction of concepts.

As mentioned in the results section, the analysis of the conceptual questions differentiates this study from both quantitative and qualitative perspectives. According to the theories presented herein, the knowledge-building process emphasises thinking about, and reflecting upon, the problem at hand, which goes far beyond calculations and the mechanical application of pre-established formulae or procedures. Students continuously have difficulty understanding the Young's modulus until the end of the engineering course, regardless of whether they have managed to solve the numerical problems provided, thereby highlighting the importance of this study.

Some limitations can be seen in the experiment. The first one refers to the relatively small sample, which can be overcome with the performing of a greater number of questions, as it is not always possible, in this type of experiment, samples with a great number of students. Another limitation is that the comparison took place between two different classes, the ideal being, if possible, for the same class to be divided into two groups, one being the control group, under traditional classes, and the other the group that will perform the experiment. It is also important to highlight that the experiment must take into account the context of each reality, and can also be used to teach the spring's elasticity constant, in Physics studies in High School and at the beginning of university courses in the STEM area.

Finally, it should be noted that, despite the limitations regarding its applicability, as a single-case approach, this study may encourage educators of STEM to conduct practical 
experiments and assess the impact on student learning. In this way, the method presented herein can be used as a future path.

\section{ACKNOWLEDGEMENTS}

We thank the engineer Daniel Cortinovis for systematising the data during his scientific initiation of this study, and Professor Éder Julio Kinast, for helping with the statistical approach.

\section{REFERENCES}

ARRUDA, S. M.; SILVA, M. R.; LABURÚ, C. E. Laboratório didático de física a partir de uma perspectiva kuhniana. Investigações em Ensino de Ciências, v. 6, n. 1, p. 97-106, 2001.

BEER, F. P., JOHNSTON, E. R.; Mechanics of Materials. New York, Mc Graw Hill 2006.

BRIEDE, B. (2013) A constructivist approach in engineering education, in: Proceedings of the 12th International Scientific Conference Engineering for rural development, pp. 584- 589. (Jelgava, Latvia)

CABRAL, T. C. B.; Metodologias alternativas e suas vicissitudes: Ensino de matemática para engenharias. Perspectivas da Educação Matemática, v. 8, n.17, p. 208$245,2015$.

CAMPBELL, D. T., STANLEY, J. C.; Experimental and Quasi-Experimental Designs for Research. Ravenio Books, 2015.

GADOTTI, M. História das Ideias Pedagógicas. São Paulo: Editora Ática, 2003.

GOULART, I. B.; Piaget: Experiências Básicas para Utilização Pelo Professor. Petrópolis: Editora Vozes, 1996.

HOOKE'S LAW: STRESS AND STRAIN REVISITED. Available in: $<$ https://www.pinterest.ch/pin/836543699514491914/?send=true>. Retrieved 7 Sep 2020.

KUHN, T. The Structure of Scientific Revolutions (3rd ed.) (Chicago: University of Chicago, 1996. 
MCCRUM, D. P. Evaluation of creative problem-solving abilities in undergraduate structural engineers through interdisciplinary problem-based learning, European Journal of Engineering Education, v. 42, n. 6, p. 684-700, 2017. DOI: 10.1080/03043797.2016.1216089

MORO, F. T.; COPPI, E. P.; PRSYBYCIEM, M. M. Construção de um biodigestor: uma proposta de Ensino interdisciplinar para escolas do campo. Revista Insignare Scientia, v. 2, n. 1, p. 104-115, Jan./Apr. 2019. DOI: 10.36661/25954520.2019v2i1.10749

OSTERMANN, F. A Epistemologia de Kuhn. Caderno Brasileiro de Ensino de Física, v. 13, n.3, p.184-196, dez.1996.

PIAGET, J. Genetic Epistemology by Jean Piaget. New York: W. W. Norton, 1981.

RIFKIN, J. Zero Marginal Cost Society. The Internet of Things, the Collaborative Commons, and the Eclipse of Capitalism. New York: Palgrave Macmillan, 2014. ISBN 978-1-137-27846-3

ROJTER, J. PBL and Constructivism in Engineering Education, in: Proceedings of the 37th SEFI Conference 2009: Attracting Young People to Engineering: Engineering is fun? Rotterdam: European University Association, 2009.

SISTEMAS ESTRUTURAIS NA ARQUITETURA. Available in: $<$ http://estruturasarquitetonicas.blogspot.com/2012/03/tomo-i-capitulo-viideformacao.html>. Accessed on 4 April 2020.

STRESS-STRAIN CURVE. Available in: $<$ https://www.cimm.com.br/portal/material_didatico/6537-a-curva-tensaodeformacao\#.XmQ13JNKjuQ>. Accessed on 4 April 2020

SUÁREZ SILVA, J.; FORTES BRAIDANTE, M. Aprendizagem significativa: concepções na formação inicial de professores de Ciências. Revista Insignare Scientia RIS, v. 1, n. 1, 18 jun. 2018.

SUROVEK, A.; RASSATI, G. Is structural engineering education creating barriers to innovation and creativity? in: Proceedings of the 6th Structural Engineers World Congress. Cancun: UNA, 2017. 
VENQUIATURO, L. D.; DALLAGO, M. R.; SCHNORRENBERGER, L. O. Pressão de vapor e evaporação. Revista Insignare Scientia, v. 1, n. 2, p. 1-11, May/Aug 2018. DOI: $10.36661 / 2595-4520.2018 v 1 i 2.11111$

VIIRI, J. Teaching the force concept: A constructivist teaching experiment in engineering education. European Journal of Engineering Education, v. 21, n. 1, p. 55 63, 1996. DOI: 10.1080/03043799608923388

WHAT IS YOUNG'S MODULUS OR MODULUS OF ELASTICITY? Available in: <https://www.pinterest.ch/pin/836543699514491914/?send=true>. Retrieved 7 Sep 2020.

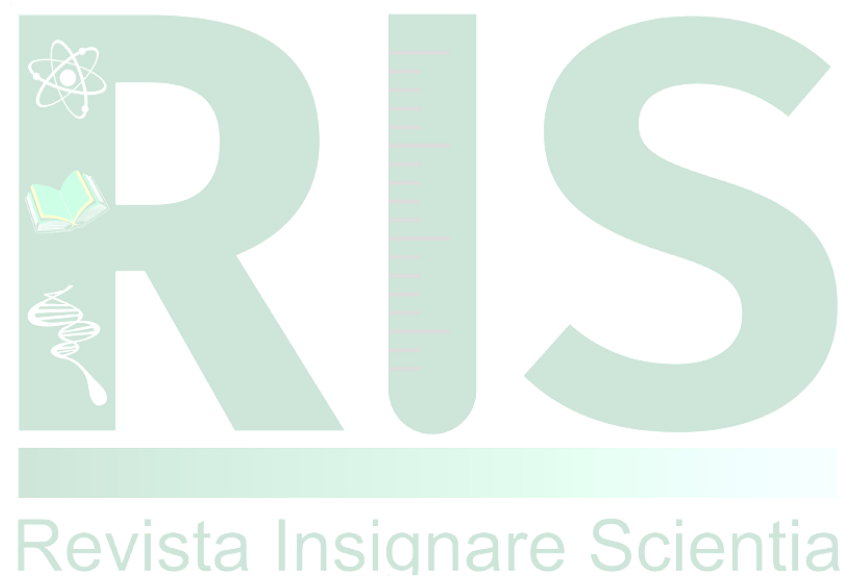

